\title{
Mechanochemical synthesis of eco-friendly fertilizer from eggshell (calcite) and $\mathrm{KH}_{2} \mathrm{PO}_{4}$
}

Roger Borges $^{1}$; Amanda Soares Giroto ${ }^{1}$, Rodrigo Klaic ${ }^{1,2}$, Fernando Wypych ${ }^{3}$, Caue Ribeiro $^{1 *}$

${ }^{1}$ Embrapa Instrumentation, 1452 XV de Novembro Street, São Carlos, SP, Zip Code:13560-970, Brazil.

${ }^{2}$ Universidade Federal de São Carlos, Departamento de Engenharia Química, Rod. Washington Luiz, km 235, São Carlos, SP, Zip Code: 13565-905, Brazil.

${ }^{3}$ Departamento de Química, Universidade Federal do Paraná, CP 19032, Zip Code: 81531-980 Curitiba-PR, Brazil.

*caue.ribeiro@embrapa.br

\begin{abstract}
:
The present article, based on reverse logistic, provides an environmentally beneficial and cost-effective method of producing calcium phosphate bioceramics (potassium calcium phosphates) aimed for soil conditioning, by a free-solvent mechanochemical process between eggshell waste and $\mathrm{KH}_{2} \mathrm{PO}_{4}$. The $\mathrm{K}_{3} \mathrm{CaH}\left(\mathrm{PO}_{4}\right)_{2}$ and possibly $\mathrm{CaKPO}_{4}$ phases formed provide a better nutrient management of $\mathrm{P}, \mathrm{K}$ and $\mathrm{Ca}$, when applied in soil system the material first release $\mathrm{K}$ and form hydroxyapatite and important $\mathrm{P}$ and $\mathrm{Ca}$ bioavailable source at $\mathrm{pH} \sim 5$, which comprises a large part of many countries soils.
\end{abstract}

Key-words: smart fertilizer, potassium calcium phosphates, eggshell, $\mathrm{KH}_{2} \mathrm{PO}_{4}$, nutrient management. 


\section{Introduction}

Nowadays, the production of new materials is closely related to the reverse logistics, considered one of most important instruments for applying shared responsibility for the products lifecycle. Reverse logistics is an instrument of economic and social development characterized by a set of actions, procedures and means to enable the collection and restitution of solid waste to the business sector, for reuse, in its cycle or in other cycles productive, or other environmentally appropriate final destination (Tibben and Lembke, 2002), the reverse logistic is perfectly applied in the agriculture context. An application of this concept is to provide novel processes for the synthesis of different calcium and / or potassium phosphates from any source of calcium carbonate $\left(\mathrm{CaCO}_{3}\right)$, making it a soil conditioner. Among sources, eggshells are important wastes of food industries and excellent $\mathrm{CaCO}_{3}$ sources (more specifically calcite) (Byeon, 2016), with monobasic potassium dihydrogen phosphate. Everyday millions of tons of eggshells are produced as biowaste around the world, disposed in landfills with no pretreatment and producing odors due to microbial growth.

Normally the reactions are processed by solid state mechanochemical activation, to produce different materials concerning physico-chemical features, especially the solubilization and diffusion of its constitutional elements and chemical species. Basically, the solid-state mechanochemical activation consists in applying mechanical energy to promote a chemical reaction (Kouznetsov et al., 2016) from solid reagents using mainly friction and impact forces (Borges et al., 2015; Borges et al., 2016; Borges et al., 2017; Borges et al., 2018; Borges et al., 2019; Borges and Wypych, 2019). The process mechanism involved is still quite complex to evaluate, but the applied energy must be large enough to be able to break the reagent bonds and promote solid phase ion migration, in the case of this study, to form a new structure. 
The process mainly produces $\mathrm{K}_{3} \mathrm{CaH}\left(\mathrm{PO}_{4}\right)_{2}$ and possibly $\mathrm{CaKPO}_{4}$, among other non-crystalline compounds and also $\mathrm{CO}_{2}$ resulting from $\mathrm{CaCO}_{3}$ decomposition. Compared to $\mathrm{KH}_{2} \mathrm{PO}_{4}$, all these phosphates may exhibit very different solubility according to the different bonds between different metal cations. It is influenced by the size of the metal cation and its charge, influencing the reticular energy of the structure (Jenkins et al., 1999). Besides that, the experimental release essays reveal that potassium dihydrogen phosphate exhibits much faster solubilization behavior than calcium or calcium and potassium phosphates. Composed solely of fertilizer components $\left(\mathrm{HPO}_{4}{ }^{2-} / \mathrm{PO}_{4}{ }^{3-}, \mathrm{Ca}^{2+}\right.$ and $\mathrm{K}^{+}$) (Liu and Lal, 2015), the produced potassium calcium phosphates may be classified as smart release fertilizers, since they provide a delay of the bioavailability of $\mathrm{P}$ and $\mathrm{K}$ and also improve the bioavailability of $\mathrm{Ca}$ turning these materials an excellent alternative in these nutrient management. In addition, the solid-state mechanochemical activation allows the reactions to occur in a solvent-free environment (Zhao et al., 2020; Wang et al., 2018), producing no liquid or solid waste in the process, ensuring huge savings during the production process (Mujumdar and Huang, 2007).

The literature reports the mechanochemical synthesis of hydroxyapatite $\left(\mathrm{Ca}_{10}\left(\mathrm{PO}_{4}\right)_{6}(\mathrm{OH})_{2}\right)$ from different precursors to those reported in this study (Chaikina et al., 2019), and even if from eggshell, the method uses phosphoric acid solution instead of powder phosphate salts (Francis and Rahman, 2016). Thus, as far as the authors know, no mechanochemical process has been reported for the production of calcium and potassium hydrogen phosphate $\left(\mathrm{K}_{3} \mathrm{CaH}\left(\mathrm{PO}_{4}\right)_{2}\right)$ and potassium calcium phosphate $\left(\mathrm{CaKPO}_{4}\right)$ from calcite provide by eggshell and $\mathrm{KH}_{2} \mathrm{PO}_{4}$, i.e. different structures from hydroxyapatite including potassium as one of the main components. It is in this sense that new technologies of ecological fertilizer production have been prioritizing 
environmental care using industrial and other potential wastes in the formulation of new products (Ivanov et al., 2019; Krishna et al., 2017; Santos et al., 2019; Cichy et al., 2019), avoiding unnecessary economic losses, are primarily relevant in the current socio-environmental scenario.

\section{Materials and Methods}

The eggshells were collected by the authors in their homes, washed with water and dried at room temperature, presenting a diameter between 1 and $10 \mathrm{~mm}$ before the grinding process; The $\mathrm{KH}_{2} \mathrm{PO}_{4} \mathrm{PA}$ was supplied from Vetec.

The milling process was performed with high-energy ball mill, Fritsch Pulverisette 7, with a $250 \mathrm{ml}$ zirconia bowl, 5 zirconia balls of $15 \mathrm{~mm}$ diameter. The essays were performed using the weight ratio of $1: 1(\mathrm{w} / \mathrm{w})$ of eggshell and $\mathrm{KH}_{2} \mathrm{PO}_{4}$ were performed firstly for $15 \mathrm{~min}, 30 \mathrm{~min}, 1 \mathrm{~h}, 2 \mathrm{~h}, 3 \mathrm{~h}, 6 \mathrm{~h}, 12 \mathrm{~h}$ and $24 \mathrm{~h}$ at $600 \mathrm{rpm}$, and secondly at 100,200, 400 and $600 \mathrm{rpm}$ for $2 \mathrm{~h}$, in order to evaluate acid-basic reactions between these precursors to form potassium calcium phosphates. Considering the purity of $\mathrm{KH}_{2} \mathrm{PO}_{4}$ and assuming that the eggshells are mainly composed by $\mathrm{CaCO}_{3}$, the mixture corresponds to $0.75 \mathrm{mmol}$ of $\mathrm{KH}_{2} \mathrm{PO}_{4}$ and $1 \mathrm{mmol}$ of $\mathrm{CaCO}_{3}$. After milled, the samples were characterized by X-ray diffraction (XRD), nuclear magnetic resonance, magic-angle spinning (NMR) MAS, thermogravimetric analysis (TGA), and differential scanning calorimetry (DSC). Details of each characterization are described in Supplementary Material.

The nutrient content of the samples and precursors were obtained dissolving the samples by using acid digestion in $\mathrm{H}_{2} \mathrm{SO}_{4} / \mathrm{H}_{2} \mathrm{O}_{2}$ PA mixture $(8: 1 \mathrm{v} / \mathrm{v}$, by $24 \mathrm{~h}$ at 250 ${ }^{\circ} \mathrm{C}$ ), and determined by atomic absorption ( $\mathrm{K}$ and $\mathrm{Ca}$ ) and colorimetric $(\mathrm{P})$ methods (Table S1, Supplementary Materials). Before release essays at citric acid solution (2 $\mathrm{wt} \%$ ), the material has been pelletized to simulated commercial products. The pellets 
were obtained in steel pelletizer applying the pressure of 5 bar, and the weight was standardized to $100 \mathrm{mg} / \mathrm{L}$ of $\mathrm{P}$. One single pellet were used in each essay in triplicate, that was placed in $10 \mathrm{~mL}$ beaker, this small beaker was immersed into $300 \mathrm{~mL}$ of $2 \%$ citric acid solution in a $600 \mathrm{~mL}$ beaker, the system was kept closed with polyvinyl chloride (PVC) film, in a constant temperature room at $25^{\circ} \mathrm{C}$ and under a magnetic stirring. The stirring ensures homogeneous distribution of diffused elements, and aliquots of $1.2 \mathrm{~mL}$ at different times (from $15 \mathrm{~min}$ to 30 days) have been collected to evaluate the release behavior and allow the calculation of a release kinetic model of $\mathrm{Ca}$, $\mathrm{K}$ and $\mathrm{P}$.

The phosphorus diffusion rates in soil were performed in Petri dishes containing moist soil, according to the method described by Degryse and Mclaughlin (2014). This method consists to use a pre-treated paper to mark the P diffusion in soil. In each Petri dish with diameter of $8.6 \mathrm{~cm}, 78 \mathrm{~g}$ of dry and sieved $2.0 \mathrm{~mm}$ mesh soil were added to achieve the desired density of $1.2 \mathrm{~g} . \mathrm{cm}^{-3}$. The chemical and physical soil properties are shown in Table S2. In order to achieve $70 \%$ of the maximum soil water retention capacity, $15 \mathrm{~mL}$ deionized water were added. The papers are scanned and analyzed using image software (GNU Image Manipulation Program, v. 2.6.11, Free Software). The scanned images are converted to black-with binary images, using a threshold color value (e.g. on a 0-255 scale), and the area of the high P-zone is quantified using the histogram command.

In order to investigate the release behavior closer to real conditions, soil release essays were carried out under aerobic conditions in plastic container containing $50 \mathrm{~g}$ of sandy soil (Table S2) with $75 \%$ water saturation. The experiments were performed at 3 , 7, 15 and 30 days, using a single pellet for each container, the pellet weight was standardized to $300 \mathrm{mg}$ of $\mathrm{P}$ per $\mathrm{kg}$ of soil. After each release period the solid residues 
samples were removed from the soil and characterized by XRD; potassium and calcium were extracted from the soil by $\mathrm{HCl}(0.05 \mathrm{Mol} / \mathrm{L})$ and $\mathrm{KCl}(1 \mathrm{Mol} / \mathrm{L})$ methods, respectively; and phosphorus was extracted from soil using Mehlich 1 method (Embrapa, 1979).

A colorimetric analyses of molybdenum blue was used to quantify phosphorus released content into the solution (Murphy and Riley, 1962) and potassium and calcium released content were quantify by flame atomic absorption spectroscopy (FAAS), with a PerkinElmer PinAAcle 900T instrument, in flame atomization mode.

\section{Results and Discussion}

The XRD patterns of the powders obtained after milling are shown in Fig. 1. The milling process between $\mathrm{KH}_{2} \mathrm{PO}_{4}$ and eggshell $\left(98 \%\right.$ of $\left.\mathrm{CaCO}_{3}\right)$ performed from $2 \mathrm{~h}$ and $400 \mathrm{rpm}$ produce a mixture of phosphates, mainly $\mathrm{K}_{3} \mathrm{CaH}\left(\mathrm{PO}_{4}\right)_{2}\left(\mathrm{PDF}\right.$ database $\mathrm{n}^{\circ} 22$ 1218 indicated by black columns, and black dash lines guiding the comparison with the samples) and possibly $\mathrm{CaKPO}_{4}\left(\mathrm{PDF}\right.$ database $\mathrm{n}^{\circ}$ 33-1002 indicated by red columns, and red dash lines guiding the comparison with the samples). Bellow these milling parameters (time and milling speed) only the reactants diffraction patterns are found, i.e., no evidence of chemical reaction is observed. There is a direct relationship between the time and milling speed and the increasing of total energy involved. In general, it was noticed that only a minimal energy is required to initiate the mechanochemical reaction and, as a consequence, the diffraction patterns have huge changes attributed to the formation of different polymorphic potassium calcium phosphate phases. When milling time increases, secondary reactions begin, for example, mechanochemical dehydroxylation of the new formed phosphates. One can propose the non-stoichiometric reaction of the main products, with $\mathrm{CaKPO}_{4}$ more evident after $24 \mathrm{~h}$ of milling: 


$$
\mathrm{KH}_{2} \mathrm{PO}_{4}+\mathrm{CaCO}_{3} \stackrel{\text { milling }}{\longrightarrow} \mathrm{CO}_{2}+\mathrm{H}_{2} \mathrm{O}+\mathrm{K}_{3} \mathrm{CaH}\left(\mathrm{PO}_{4}\right)_{2}+\mathrm{CaKPO}_{4}
$$

Figure 1

The TGA curve of $\mathrm{KH}_{2} \mathrm{PO}_{4}$ show two main loss events: since it is an anhydrous material, the moisture loss is not seen and the first step at $200^{\circ} \mathrm{C}$ should be associated to crystallization water loss. The second step at $300^{\circ} \mathrm{C}$ corresponds to polycondensation, concomitant with structural water loss. The residual mass $(89 \%)$ regards to $\mathrm{KPO}_{3}$ formation is consistent to the theoretical (87\%) (Fig. 2):

$$
\mathrm{KH}_{2} \mathrm{PO}_{4} \stackrel{\Delta}{\rightarrow} \mathrm{H}_{2} \mathrm{O}+\mathrm{KPO}_{3}
$$

The thermal degradation of eggshell has two main steps: a first mass loss step below $300{ }^{\circ} \mathrm{C}$ attributed to moisture elimination concomitant with organic membrane degradation; and a second step related to calcite decomposition below $700{ }^{\circ} \mathrm{C}$ (Cree and Rutter, 2015; Omari et al., 2016). The eggshells are mainly composed by $\mathrm{CaCO}_{3}$, as attested by XRD pattern (Fig. 1), which is also confirmed by the small difference from experimental residue (56\%) and the theoretical (59\%):

$$
\mathrm{CaCO}_{3} \stackrel{\Delta}{\rightarrow} \mathrm{CO}_{2}+\mathrm{CaO}
$$

In the case of milled samples (Fig. 2), three mass loss events are observed: the first step, centered at $280^{\circ} \mathrm{C}$, is related to crystallization water loss concomitant with physically adsorbed moisture elimination. The second step, centered at $420^{\circ} \mathrm{C}$, is associated to partial structural water loss and structure dimerization, and the final step, centered at $710^{\circ} \mathrm{C}$ corresponds to final structural water loss reaction and structure polycondensation (Vlase et al., 2005). In addition, all the samples milled at $600 \mathrm{rpm}$ do not present of calcite decomposition below $700{ }^{\circ} \mathrm{C}$ but in the samples milled for $2 \mathrm{~h}$ at $400 \mathrm{rpm}$ this event is still observed. It suggests that in low rotation speeds do not 
provide enough energy to degrade the total amount of calcite to form calcium potassium phosphates. It is observed that all samples processed at $600 \mathrm{rpm}$ present a similar thermal decomposition, but with different residuals masses according to the milling time. Water loss at $340^{\circ} \mathrm{C}$ reduces with milling time probably due to water formation and adsorption during the process and subsequently desorption increasing time milling.

Figure 2

Thus, to better understand these differences and the effect of milling process in material structure, the milled samples were calcined to characterize the solid fractions after each main loss mechanism $\left(280{ }^{\circ} \mathrm{C}, 420^{\circ} \mathrm{C}\right.$ and $\left.710^{\circ} \mathrm{C}\right)$ (Fig. 3). In all cases, a similar thermal behavior related to crystalline phases formation was identified - except for milling during $2 \mathrm{~h}$ at $600 \mathrm{rpm}$, this sample has an unclear phosphate phase, but after thermal treatment at $280{ }^{\circ} \mathrm{C}$ it slightly changes matching with $\mathrm{K}_{3} \mathrm{CaH}\left(\mathrm{PO}_{4}\right)_{2}$ phase (Supplementary Material, Fig. S1). For the other samples, the treatment at $280^{\circ} \mathrm{C}$ did not affected the phase $\mathrm{K}_{3} \mathrm{CaH}\left(\mathrm{PO}_{4}\right)_{2}$ (PDF database $n^{\circ}$ 22-1218), confirming that the mass losses observed in Fig. 2 regard to unbounded water. On the other hand, the thermal treatment at $420^{\circ} \mathrm{C}$ converted the samples to $\mathrm{KCaPO}_{4}\left(\mathrm{PDF}\right.$ database $\mathrm{n}^{\circ} 33-$ 1002), which confirms that the related mass loss is associated to recrystallization by the partial thermal dehydration of the $\mathrm{K}_{3} \mathrm{CaH}\left(\mathrm{PO}_{4}\right)_{2}$ phase that may still be present in the samples. After thermal treatment at $710{ }^{\circ} \mathrm{C}$, the patterns correspond to $\mathrm{KCaPO}_{4}$ phase in all cases indicating the complete conversion:

$$
\mathrm{K}_{3} \mathrm{CaH}\left(\mathrm{PO}_{4}\right)_{2} \stackrel{\text { or }}{\stackrel{\text { orlling }}{\longrightarrow}} \mathrm{H}_{2} \mathrm{O}+\mathrm{CaKPO}_{4}
$$

Figure 3 
Fig. S2 shows the DSC curves of the precursors and milled samples. DSC curves of eggshell did not present any event in the temperature analyzed. Calcite has a single endothermic peak at $726{ }^{\circ} \mathrm{C}$, related to $\mathrm{CaCO}_{3}$ conversion to $\mathrm{CaO}$, agreeing with TGA (Fig. 2) (Omari et al., 2016). For $\mathrm{KH}_{2} \mathrm{PO}_{4}$, an endothermic peak at $228{ }^{\circ} \mathrm{C}$ corresponds to the loss of one water molecule followed by the polycondensation of the structure due to the losses of the water structural. Over to this temperature are observed phase transitions connected with the breaking up of the hydrogen network which are responsible to form polyphosphate phase around $500^{\circ} \mathrm{C}$ (de Jager et al. 2011). Endothermic peaks around $57-82{ }^{\circ} \mathrm{C}$ and above $300{ }^{\circ} \mathrm{C}$ correspond to the dehydration and decomposition processes, respectively. (Tõnsuaadu et al. 2011) In lower milling times other endothermic peaks are observed, probably due to different potassium substitutions levels $\left(\mathrm{K}_{3} \mathrm{CaH}\left(\mathrm{PO}_{4}\right)_{2}\right.$ phase forming $\mathrm{KCaPO}_{4}$ phase $)$. The mechanochemical formation of $\mathrm{KCaPO}_{4}$ in longer millings reflects the shift of endothermic peak (from $455^{\circ} \mathrm{C}$ to $499^{\circ} \mathrm{C}$ ) probably due to the loss of structural water.

The ${ }^{31} \mathrm{P}$ NMR MAS spectra of the precursor $\mathrm{KH}_{2} \mathrm{PO}_{4}$ shows a single intense signal at $\delta=3.74 \mathrm{ppm}$, characteristic of monosubstituted phosphate (Godinot et al., 2017) (Fig. 4). The shift at $\delta=3.28 \mathrm{ppm}$ ( 2 and $6 \mathrm{~h}$ at $600 \mathrm{rpm})$ and at $\delta=2.82 \mathrm{ppm}(24$ $\mathrm{h}$ at $600 \mathrm{rpm})$ are reported to calcium phosphates compounds, for example, hydroxyapatite $\left(\mathrm{Ca}_{10}\left(\mathrm{PO}_{4}\right)_{6}(\mathrm{OH})_{2}\right)$ and octocalcium phosphate $\left(\mathrm{Ca}_{8} \mathrm{H}_{2}\left(\mathrm{PO}_{4}\right)_{6} .5 \mathrm{H}_{2} \mathrm{O}\right)$ (Frossard et al., 1994). In addition, the signal at $\delta=0.74 \mathrm{ppm}$ is related to disubstituted phosphate, suggesting $\mathrm{H}\left(\mathrm{PO}_{4}\right)_{2}{ }^{5-}$ species agreeing with the $\mathrm{KCaPO}_{4}$ formation.

Figure 4 
A shift was also observed at around $\delta=-5 \mathrm{ppm}$ (marked at $\delta=-4,78 \mathrm{ppm}$ ) in sample milled by $2 \mathrm{~h}$ at $600 \mathrm{rpm}$, attributed to pyrophosphate formed by phosphate dimerization (Godinot et al., 2017). It suggests that this phosphorous chemical environment is an intermediate compound during $\mathrm{K}_{3} \mathrm{CaH}\left(\mathrm{PO}_{4}\right)_{2}$ and $\mathrm{KCaPO}_{4}$ formation.

\subsection{Solubility kinetics}

The kinetic study of the nutrient release was firstly evaluated in citric acid solution (wt 2\%) according to the recommended procedure from MAPA to analyze fertilizer solubility (MAPA, 2014) (Fig. 5), and according to the total content of each nutrient in the samples and precursors (Table S1).

Figure 5

Phosphorus and potassium release behavior were similar for the precursor $\left(\mathrm{KH}_{2} \mathrm{PO}_{4}\right)$ and milled samples, but slower for milled samples, this fact shows that the phosphates obtained by milling improve the nutrients management maintaining their bioavailability. On the other hand, calcium release is rather different for eggshell to the milled samples. Even that $\mathrm{CaCO}_{3}$ in the eggshell may be soluble in acids, the kinetic was extremely slow in comparison, evidencing the solubility of phosphates formed.

The nutrients release curves were fitted using the linear form of pseudo-first order, pseudo-second order and intraparticle diffusion models - used in the literature. But, phosphorus and potassium presented better correlation with pseudo-second order model, considering ' $\mathrm{R}$ ', and the values related to concentration at equilibrium time "qe" and "experimental qe" (Table 1). For both nutrients there was a substantial decrease of the kinetic constant from $\mathrm{KH}_{2} \mathrm{PO}_{4}$ to milled samples, attesting the delay in nutrient supply after mechanochemical processing and certainly related to the formation of potassium calcium phosphate phases $\left(\mathrm{K}_{3} \mathrm{CaH}\left(\mathrm{PO}_{4}\right)_{2}\right.$ and $\left.\mathrm{KCaPO}_{4}\right)$. Even not possible 
to compare kinetic constants for the calcium release, it is important to highlight that in this case was observed an opposite effect: the new phosphates phases from milling made calcium readily available. Thus, considering the kinetic behavior, it was observed that these materials would promote better nutrient management by delaying the bioavailability of phosphorus and potassium (which are highly soluble from $\mathrm{KH}_{2} \mathrm{PO}_{4}$ ) and increasing the calcium bioavailability.

Table 1

\subsection{Soil release essays}

The kinetic study of the nutrient release was also evaluated in soil (Fig. 6). The temporal profile for the precursor $\mathrm{KH}_{2} \mathrm{PO}_{4}$ indicates a $\mathrm{P}$ increase from $0 \mathrm{mg} / \mathrm{kg}$ to 107 $\mathrm{mg} / \mathrm{kg}$ after 3 days of release keeping constant after 30 days, representing $40 \%$ of total $\mathrm{P}$ from precursor $\left(\mathrm{KH}_{2} \mathrm{PO}_{4}\right)$. Differently, for sample $2 \mathrm{~h} / 600 \mathrm{rpm}$, the phosphorus release is more progressive (from $0 \mathrm{mg} / \mathrm{kg}$ to $25 \mathrm{mg} / \mathrm{kg}$ at 3 days and $45 \mathrm{mg} / \mathrm{kg}$ at 30 days) corresponding to $15 \%$ of total $\mathrm{P}$ content recovered from the milled sample. These results indicate that sample $2 \mathrm{~h} / 600 \mathrm{rpm}$ presented a longer delay in phosphorus release compared to the precursor $\left(\mathrm{KH}_{2} \mathrm{PO}_{4}\right)$, corroborating with the results observed in citric acid solution.

In addition, an extra experiment was done to visualization of the $\mathrm{P}$ diffusion zone and comparison with $\mathrm{KH}_{2} \mathrm{PO}_{4}$ and Struvite. Then, Fig. S3 and S4, show the $\mathrm{P}$ radial diffusion for the sample $2 \mathrm{~h} / 600 \mathrm{rpm}$ in soil compared to the precursor $\left(\mathrm{KH}_{2} \mathrm{PO}_{4}\right)$ and struvite (a low P diffusion material with ideal formula $\mathrm{NH}_{4} \mathrm{MgPO}_{4} \cdot 6 \mathrm{H}_{2} \mathrm{O}$ ) (Talboys et al., 2016; Borges et al., 2018) after 2 and 30 days of fertilizers application. At day 2 it is possible to see that struvite was not able to release any phosphorus, while sample 
$2 \mathrm{~h} / 600 \mathrm{rpm}$ the $\mathrm{P}$ diffusion reach a value of $1.99 \mathrm{~cm}$ a significant value compared to 2.62 cm for $\mathrm{KH}_{2} \mathrm{PO}_{4}$, a source of $\mathrm{P}$ considered extremely soluble. After 30 days, struvite starts $\mathrm{P}$ delivery, but sample $2 \mathrm{~h} / 600 \mathrm{rpm}$ has a control release keeping lower values compared to $\mathrm{KH}_{2} \mathrm{PO}_{4}$. In summary, results showed that the $\mathrm{P}$ radial diffusion profile from sample milled for $2 \mathrm{~h} / 600 \mathrm{rpm}$ is intermediate, $34 \%$ faster than struvite and $22 \%$ slower than precursor at the end of 30 days. The kinetic study of K release in soil shows a slight decrease at 3 days when $2 \mathrm{~h} / 600 \mathrm{rpm}$ sample is compared to $\mathrm{KH}_{2} \mathrm{PO}_{4}$, after that, both materials reach around $100 \%$ release (Fig. 6).

Figure 6

There is no increase in the bioavailable calcium when eggshell precursor $\left(\mathrm{CaCO}_{3}\right)$ is applied in soil, but this concentration increases to $30.97 \mathrm{mg} / \mathrm{kg}$ after 30 days for $2 \mathrm{~h} / 600 \mathrm{rpm}$ sample, corresponding to around $8 \%$ of calcium recovery from sample (Fig. 6). These results corroborate with citric acid solution release essays and attest efficient use of $2 \mathrm{~h} / 600 \mathrm{rpm}$ sample as a source of bioavailable calcium compared to the precursor eggshell $-\mathrm{CaCO}_{3}$. The slower release for calcium and phosphorus for $2 \mathrm{~h} / 600$ rpm sample and the P radial diffusion are probably related to hydroxyapatite formation $\left(\mathrm{Ca}_{10}\left(\mathrm{PO}_{4}\right)_{6}(\mathrm{OH})_{2}\right)$ (PDF database $\mathrm{n}^{\circ}$ 9-432 indicated by green columns) - identified from 3 until 30 days in soil conditions (Fig. 7). In an additional experiment, samples ground at $600 \mathrm{rpm}$ were suspended in water, dried and then characterized by XRD, in which the phase transition to Hydroxyapatite was observed for all of them (Fig. S5). Hydroxyapatite is an important long-term calcium and phosphorus slow release fertilizer (Taskin et al., 2018; Xiong et al., 2018; Ribeiro et al., 2020), turning systematically soluble by the natural soil $\mathrm{pH}$ acidification, especially under $\mathrm{pH} 5$ 
(Larsen, 1966). On the other hand, if faster release is required an excellent alternative for sample $2 \mathrm{~h} / 600 \mathrm{rpm}$ would be the use as nanocomposites as well as verified in the work of Giroto et al. (2017), where the authors reported the preparation of a composite of hydroxyapatite particles dispersion in matrix of urea and starch to promote better solubilization of $\mathrm{P}$ and $\mathrm{Ca}$.

Figure 7

\section{Conclusions}

Based on the reverse logistic and green chemistry this study proposes the use of eggshell, a food industry residue, and $\mathrm{KH}_{2} \mathrm{PO}_{4}$ to design an eco-friendly fertilizer that guarantee a better nutrient management, playing on the solubility of calcium, potassium and phosphorus. To reach this aim a mechanochemical process was used, free of solvent, and presenting no unwanted subproduct. The results indicate new phosphate phases such as $\mathrm{K}_{3} \mathrm{CaH}\left(\mathrm{PO}_{4}\right)_{2}$ and $\mathrm{KCaPO}_{4}$, that present in citric acid solution (wt 2\%) a slower release character of potassium and phosphorus compared to the precursor $\mathrm{KH}_{2} \mathrm{PO}_{4}$, and a faster release character compared to the precursor $\mathrm{CaCO}_{3}$ from eggshell. The soil essays performed indicate the same behavior, but a general slower release trend when compared to citric acid solution (wt 2\%) essays, this can be explained by hydroxyapatite $\left(\mathrm{Ca}_{10}\left(\mathrm{PO}_{4}\right)_{6}(\mathrm{OH})_{2}\right)$ formation, that still an important source of calcium and phosphorus as a long-term slow release fertilizer.

\section{Acknowledgments}

This work was supported by FAPESP (São Paulo State Research Foundation, grant \#2016/10636-8 and \#2018/10104-1), CNPq (Brazilian National Council for Scientific 
and Technological Development, grant 301743/2018-5), and CAPES (Coordination for the Improvement of Higher Education Personnel, Finance Code 001). The authors thank the Agronano Network (Embrapa Research Network), the Agroenergy Laboratory, and the National Nanotechnology Laboratory for Agribusiness (LNNA) for providing institutional support and facilities.

\section{References}

Borges, R., Wypych, F., 2019. Potential slow release fertilizers and acid soil Conditioners Obtained by One-Pot Mechanochemical Activation of chrysotile:cement roofing sheets with $\mathrm{K}_{2} \mathrm{HPO}_{4}$. J. Braz. Chem. Soc., 30, 2, 326332. https://doi.org/10.21577/0103-5053.20180181.

Borges, R., Wypych, F., Petit, E., Forano, C., Prevot, V., 2019. Potential sustainable slow-release fertilizers obtained by mechanochemical activation of $\mathrm{MgAl}$ and $\mathrm{MgFe}$ layered double hydroxides and $\mathrm{K}_{2} \mathrm{HPO}_{4}$. Nanomaterials 9, 183; https://doi:10.3390/nano9020183.

Borges, R.; Baika, L. M.; Grassi, M. T.; Wypych, F., 2018. Mechanochemical conversion of chrysotile/K2HPO4 mixtures into potential sustainable and environmentally friendly slow-release fertilizers. J. Environ. Manage., 15, 962. https://doi.org/10.1016/j.jenvman.2017.11.082.

Borges, R.; Brunatto, S. F.; Leitão, A. A.; Carvalho, G. S. G.; Wypych, F., 2015. Solidstate mechanochemical activation of clay minerals and soluble phosphate mixtures to obtain slow-release fertilizer. Clay Miner., 50, 153. https://doi.org/10.1180/claymin.2015.050.2.01.

Borges, R.; Dutra, L. M.; Barison, A.; Wypych, F., 2016. MAS NMR and EPR study of structural changes in talc and montmorillonite induced by grinding. Clay Miner., 51, 69. https://doi.org/10.1180/claymin.2016.051.1.06.

Borges, R.; Prevot, V.; Forano, C.; Wypych, F. 2017. Design and kinetic study of sustainable potential slow-release fertilizer obtained by mechanochemical activation of clay minerals and potassium monohydrogen phosphate. Ind. Eng. Chem. Res., 56, 708. https://doi.org/10.1021/acs.iecr.6b04378. 
Byeon, J.H., 2016. Photo-derived transformation from modified chitosan@calcium carbonate nanohybrids to nanosponges. Sci. Rep. 6, 28782. https://doi.org/10.1038/srep28782

Chaikina, M. V., Bulina, N. V., Vinokurova, O. B., 2019. Mechanochemical synthesis of apatite and tricalcium phosphate as materials for medical purposes. Mater. Today-Proc., 12, 52-56. https://doi.org/10.1016/j.matpr.2019.03.062.

Cichy, B.; Kuzdzaf, E.; Krzton, H., 2019. Phosphorus recovery from acidic wastewater by hydroxyapatite precipitation. J. Environ. Manage., 232, 421-427. https://doi.org/10.1016/j.jenvman.2018.11.072

Embrapa, Empresa Brasileira de Pesquisa Agropecuária. In: Manual de métodos de análise de solo, 2nd 388 ed. Centro Nacional de Pesquisa em Solos, Embrapa 389 Solos, Rio de Janeiro, Brazil, 1979, 212.

Francis, A. A., Rahman, M. K. A., 2016. The environmental sustainability of calcined calcium phosphates production from the milling of eggshell wastes and phosphoric acid. J. Clean. Prod. 137, 1432-1438. https://doi.org/ 10.1016/j.jclepro.2016.08.029

Frossard, E., Tekely, P., Grima, J.Y., 1994. Characterization of phosphate species in urban sewage sludges by high-resolution solid-state 31P NMR. Eur. J. Soil Sci., 45, 403-408. https://doi.org/10.1111/j.1365-2389.1994.tb00525.x

Giroto, A.S.; Guimaraes, G.G.F.; Foschini, M.; Ribeiro, C., 2017. Role of slow-release nanocomposite fertilizers on nitrogen and phosphate availability in soil. Sci. Rep. 7, 46032. https://doi.org/10.1038/srep46032

Godinot, C., Gaysinski, M., Thomas, O. P., Ferrier, C., Grover, R., 2016. On the use of ${ }^{31} \mathrm{P}$ NMR for the quantification of hydrosoluble phosphorus-containing compounds in coral host tissues and cultured zooxanthellae. Sci. Rep., 6, 21760. https://doi.org/10.1038/srep21760.

Ivanov, V., Stabnikov, V., Kawasaki, S., 2019. Ecofriendly calcium phosphate and calcium bicarbonate biogrouts. J. Clean. Prod., 218, 1, 328-334. https://doi.org/10.1016/j.jclepro.2019.01.315

Jenkins, H. D. B., Roobottom, H. K., Passmore, J., Glasser, L., 1999. Relationships among ionic lattice energies, molecular (formula unit) volumes, and thermochemical radii. Inorg. Chem., 38, 3609-3620. https://doi.org/10.1021/ic9812961 
Kilmer, V. J., Alexander, L. T., 1949. Methods of making mechanical analyses of soils. Soil Sci., 68 (1), 15-24. http://dx.doi.org/10.1097/00010694-194907000-00003

Kouznetsov, V. V., Merchán-Arenas, D. R., Martínez-Bonilla, C. A., Macías, M. A., Roussel, P., Gauthier, G. H., 2016. Grinding and Milling: Two efficient methodologies in the solvent-free phosphomolybdic ácid-catalyzed and mechanochemical synthesis of cis-4-Amido-n-yl-2-methyl-tetrahydroquinolines. J. Braz. Chem. Soc., 27, (12), 2246-2255. https://doi.org/10.5935/01035053.20160117 .

Krishna, K.C. B.; Niaz, M.R.; Sarker, D.C.; Jansen, T., 2017. Phosphorous removal from aqueous solution can be enhanced through the calcination of lime sludge. J. Environ. Manage., 200, 359-365. https://doi.org/10.1016/j.jenvman.2017.06.003

Larsen, S., 1966. Solubility of hydroxyapatite. Nature, 212, 605. https://doi.org/10.1038/212605a0

Liu; R., Lal, R., 2015. Potentials of engineered nanoparticles as fertilizers for increasing agronomic productions. Sci. Total Environ., 514, 131-139. https://doi.org/10.1016/j.scitotenv.2015.01.104.

MAPA, Ministério da Agricultura, Pecuária E Abastecimento. Manual de métodos analíticos oficiais para fertilizantes minerais, orgânicos, organominerais e corretivos / Ministério da Agricultura, Pecuária e Abastecimento. Secretaria de Defesa Agropecuária. Coordenação-Geral de Apoio Laboratorial; Murilo Carlos Muniz Veras (Org.) - Brasília : MAPA/SDA/CGAL, 2014. 220 p

Mujumdar, A. S., Huang, L. X. 2007. Global R\&D needs in drying. Dry. Technol., 25: 647-658. https://doi.org/10.1080/07373930701285886.

Murphy, J.; Riley, J. P., 1962. A Modified single solution method for the determination of phosphate in natural waters. Anal. Chim. Acta, 27, 31-36. https://doi.org/10.1016/S0003-2670(00)88444-5

Ribeiro, I. C. A., Teodoro, J. C., Guilherme, L. R. C., Melo, L. C. A., 2020. Hydroxyleggshell: a novel eggshell byproduct highly effective to recover phosphorus from aqueous solutions. J. Clean. Prod., 123042. https://doi.org/10.1016/j.jclepro.2020.123042.

Santos, A.F; Arim, A.L.; Lopes, D.V.; Gando-Ferreira, L.M.; Quina, M.J., 2019. Recovery of phosphate from aqueous solutions using calcined eggshell as an eco-friendly adsorbent. J. Environ. Manage., 238, 451-459. https://doi.org/10.1016/j.jenvman.2019.03.015 
Talboys, P.J., Heppell, J., Roose, T., Healey, J.R., Jones, D.L., Withers, P. J. A., 2016. Struvite: a slow-release fertilizer for sustainable phosphorus management? Plant Soil. 401: 109-123. https://doi.org/10.1007/s11104-015-2747-3.

Taskin, M.B.; Sahin, O.; Taskin, H.; Atakol, O.; Inal, A.; Gunes, A., 2018. Effect of synthetic nano-hydroxyapatite as an alternative phosphorus source on growth and phosphorus nutrition of lettuce (Lactuca sativa L.) plant. Journal of Plant Nutrition. 41, (9), 1148-1154. https://doi.org/10.1080/01904167.2018.1433836

Tibben-Lembke, R., 2002. Life after death: reverse logistics and the product life cycle, Int. J. Phys. Distr. Log., 32, (3), 223-244. https://doi.org/10.1108/09600030210426548

Wang, H., DeLisio, J. B., Wu, T., Wang, X., Zachariah, M. R., 2018. One-step solventfree mechanochemical synthesis of metal iodate fine powders. Powder Technol., 324, (15), 62-68. https://doi.org/10.1016/j.powtec.2017.10.024.

Xiong, L.; Wang, P.; Hunter, M.N.; Kopittke, P.M., 2018. Bioavailability and movement of hydroxyapatite nanoparticles (HA-NPs) applied as a phosphorus fertiliser in soils. Environ. Sci.: Nano. 5, 2888-2898. https://doi.org/10.1039/C8EN00751A

Zhao, J., Shan, W., Zhang, P., Dai, S., 2020. Solvent-free and mechanochemical synthesis of $\mathrm{N}$-doped mesoporous carbon from tannin and related gas sorption property. Chem. Eng. J., 381, 122579. https://doi.org/10.1016/j.cej.2019.122579.

\section{Figure List}

Figure $1-\mathrm{XRD}$ patterns of eggshells, $\mathrm{KH}_{2} \mathrm{PO}_{4}$ and the samples submitted to different milling conditions as well as the PDF pattern.

Figure 2 - TGA curves of precursors and samples milled: at 600 for 2 h, 6 h, 24 h and 2 $\mathrm{h}$ at $400 \mathrm{rpm}$ (A) and only samples milled at $600 \mathrm{rpm}$ for: $2 \mathrm{~h}, 6 \mathrm{~h}$ and $24 \mathrm{~h}(\mathrm{~B})$.

Figure 3 - XRD patterns of milled samples at $600 \mathrm{rpm}$ after thermal treatments at 280 , 420 and $710{ }^{\circ} \mathrm{C}$.

Figure $4-{ }^{31} \mathrm{P}$ NMR MAS spectra of the precursor $\mathrm{KH}_{2} \mathrm{PO}_{4}$, milled sample at $600 \mathrm{rpm}$ by: $2 \mathrm{~h}, 6 \mathrm{~h}$ and $24 \mathrm{~h}$. 
Figure 5 - Release of: phosphorus (A), potassium (B) and calcium from 0 to $80 \mathrm{~h}(\mathrm{C})$ and calcium from 0 to $800 \mathrm{~h}(\mathrm{D})$ in function of time.

Figure 6 - Soil release essay of: A- phosphorus, B- potassium and C- calcium.

Figure 7 - XRD patterns of $\mathrm{Ca} 2 \mathrm{~h} / 600 \mathrm{rpm}$ sample residues recovery after soil release essays.

Figure 1

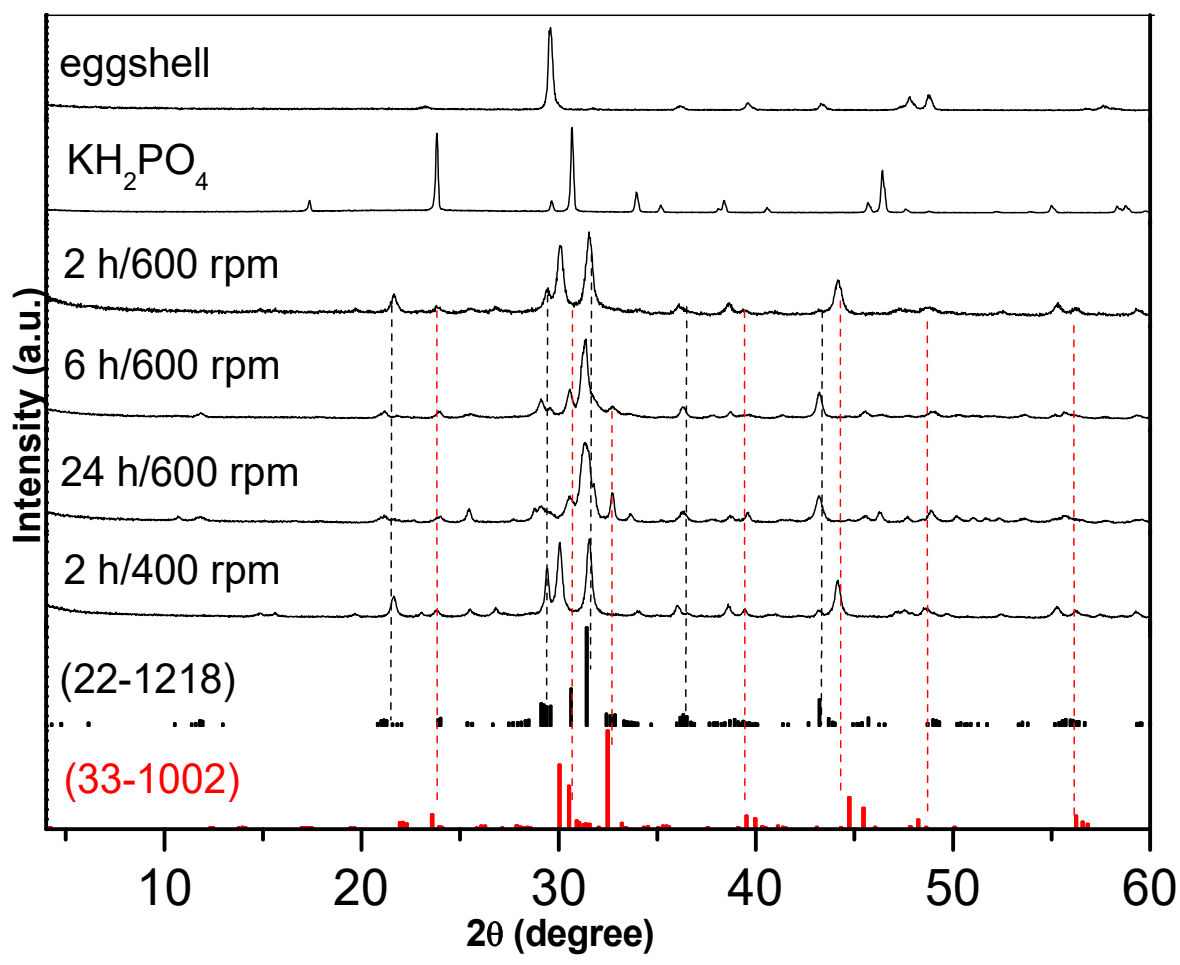


Figure 2
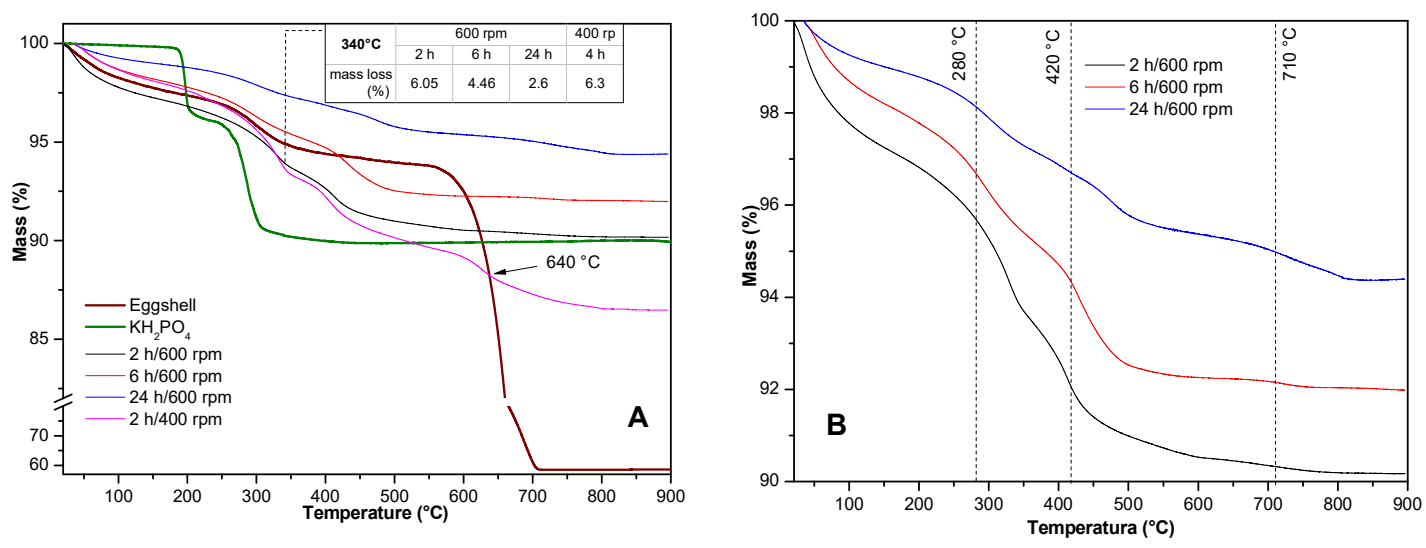

Figure 3
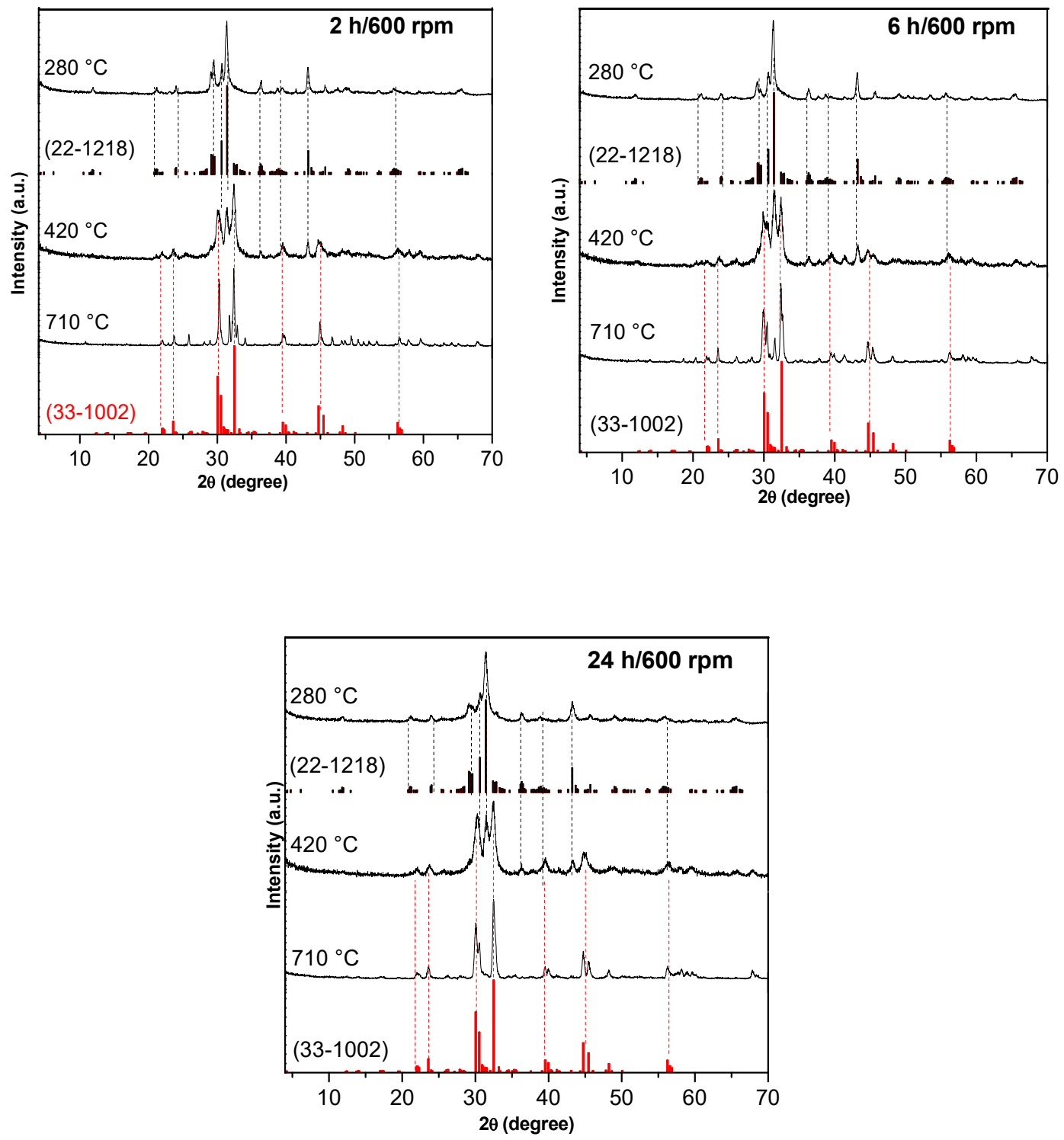
Figure 4

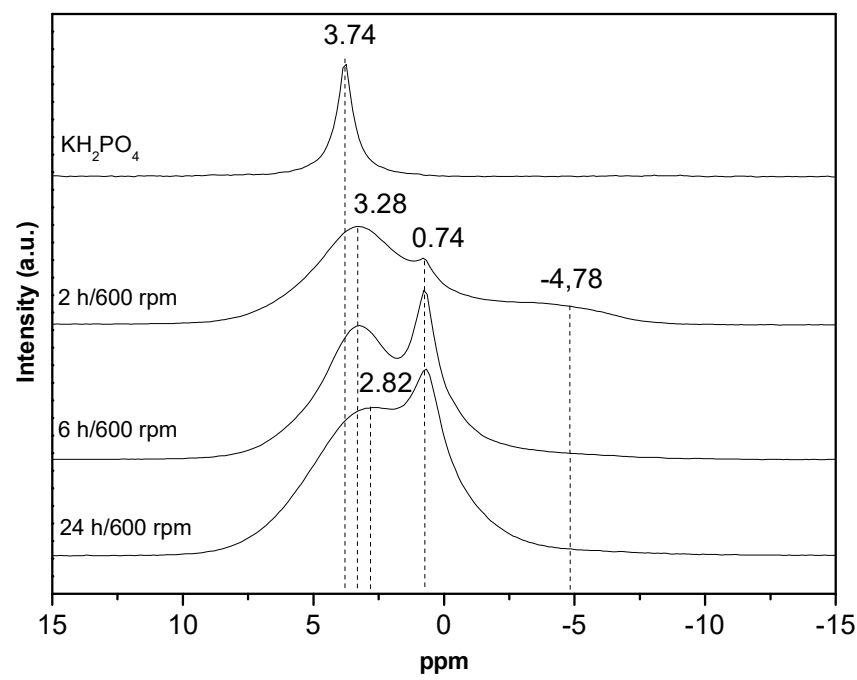

Figure 5
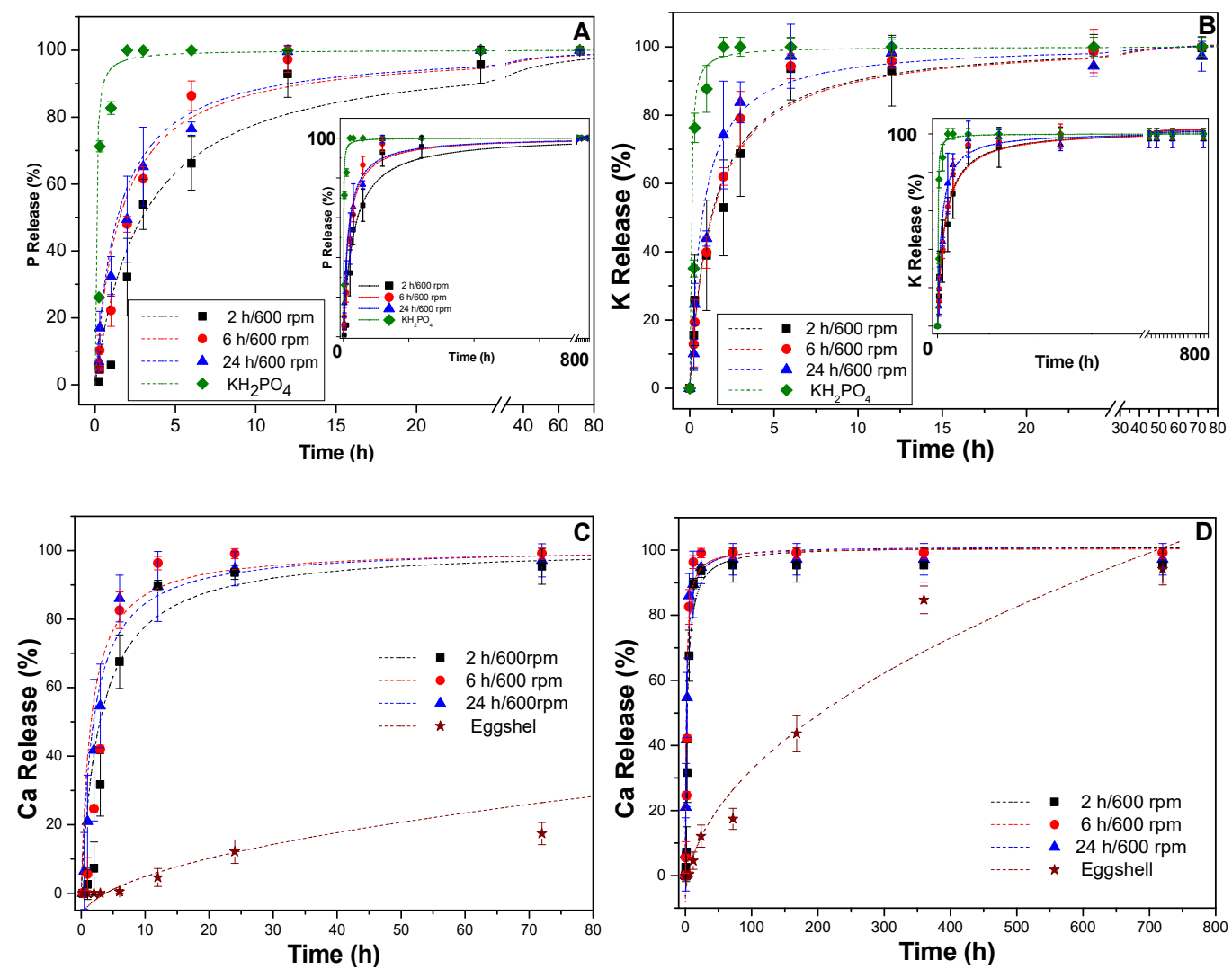
Figure 6
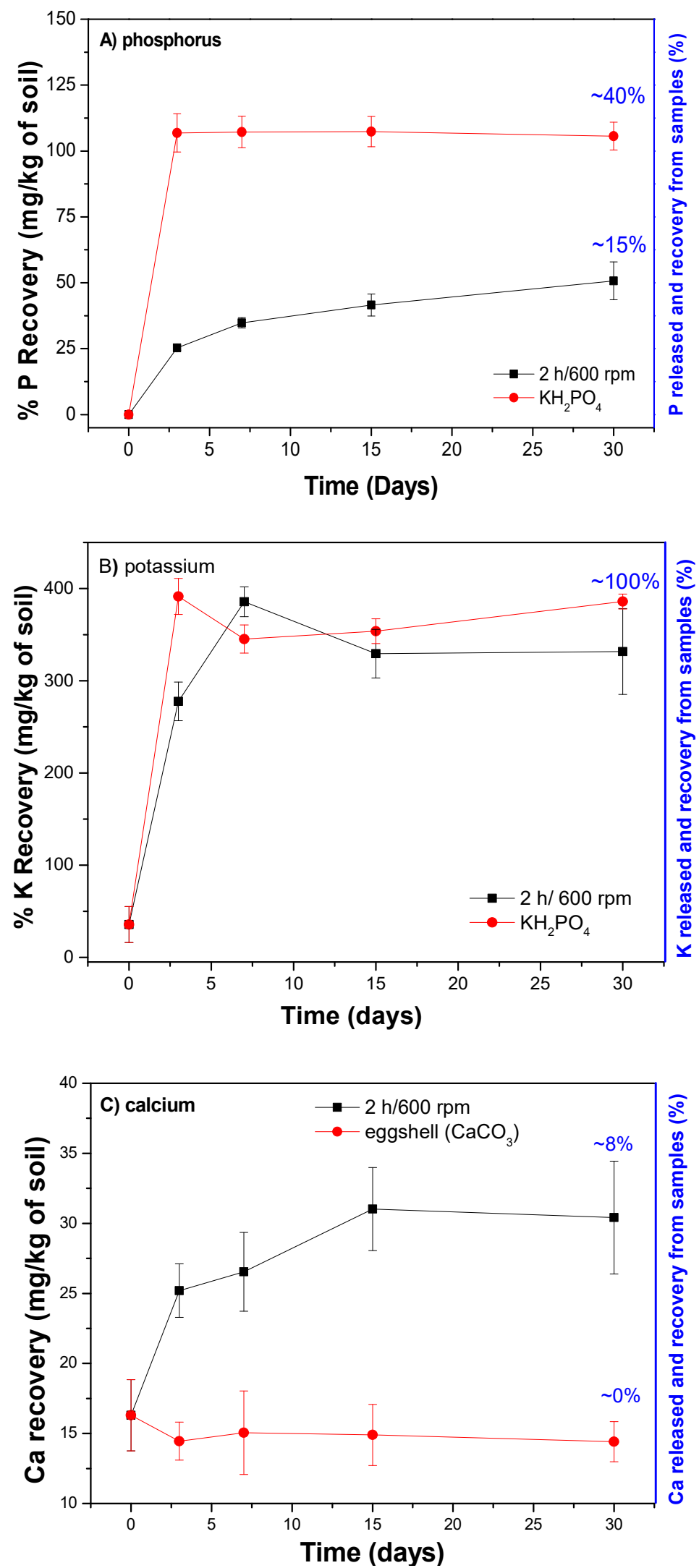
Figure 7

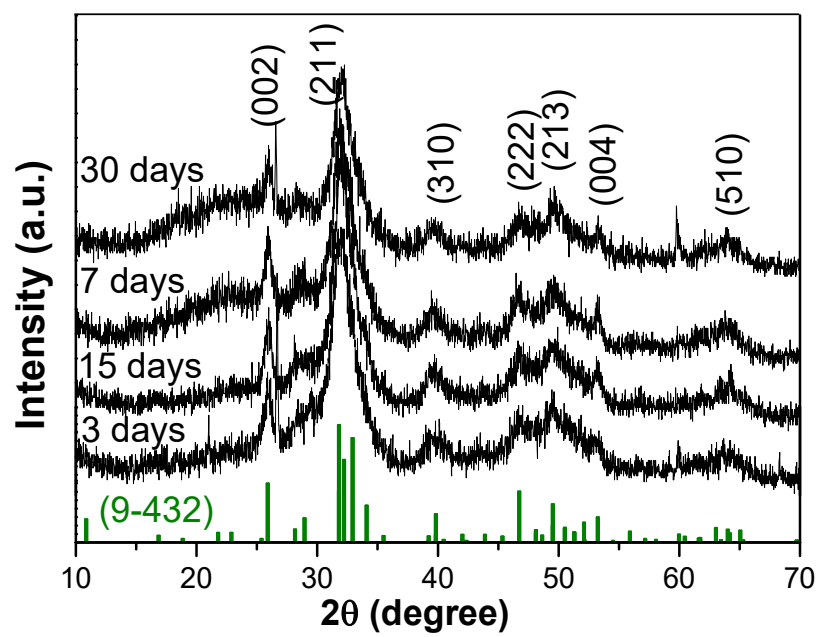

Table List

Table 1 - Kinetic parameters for phosphorus and potassium release obtained by pseudosecond order model.

\begin{tabular}{cccccc}
\hline \multirow{2}{*}{ Sample } & \multirow{2}{*}{ Element } & \multicolumn{4}{c}{ Pseudo-second order model } \\
& & KII $\left._{\mathbf{~ ( m i n}} \mathbf{- 1}\right)$ & $\begin{array}{c}\text { qe } \\
\mathbf{g} / \mathbf{L})\end{array}$ & Experimental qe (g/L) & $\mathbf{R}^{\mathbf{2}}$ \\
\hline $2 \mathrm{~h} / 600 \mathrm{rpm}$ & & 3.257 & 0.1028 & 0.1017 & 0.9997 \\
$6 \mathrm{~h} / 600 \mathrm{rpm}$ & & 6.337 & 0.1013 & 0.1007 & 0.9998 \\
$24 \mathrm{~h} / 600 \mathrm{rpm}$ & Phosphorus & 6.289 & 0.1128 & 0.1122 & 0.9999 \\
$2 \mathrm{~h} / 400 \mathrm{rpm}$ & & 5.900 & 0.1266 & 0.1259 & 0.9999 \\
$\mathrm{KH}_{2} \mathrm{PO}_{4}$ & 944.3 & 0.08006 & 0.08069 & 0.9999 \\
\hline $2 \mathrm{~h} / 600 \mathrm{rpm}$ & & 5.371 & 0.1275 & 0.1247 & 0.9997 \\
$6 \mathrm{~h} / 600 \mathrm{rpm}$ & & 5.928 & 0.1359 & 0.1331 & 0.9996 \\
$24 \mathrm{~h} / 600 \mathrm{rpm}$ & Potassium & 13.02 & 0.1013 & 0.1001 & 0.9995 \\
$2 \mathrm{~h} / 400 \mathrm{rpm}$ & & 8.688 & 0.09859 & 0.09729 & 0.9995 \\
$\mathrm{KH}_{2} \mathrm{PO}_{4}$ & & 970.4 & 0.08695 & 0.8515 & 0.9997 \\
\hline
\end{tabular}

\section{Supplementary Material}

Materials and methods.

Table S1 - total nutrient content in the samples and precursors

\begin{tabular}{lll}
\hline Samples & Nutrients & Content (\%) \\
\hline Eggshell & $\mathrm{Ca}$ & 36.1 \\
\hline $\mathrm{KH}_{2} \mathrm{PO}_{4}$ & $\mathrm{~K}$ & 28.8 \\
& $\mathrm{P}$ & 22.8 \\
\hline $4 \mathrm{~h} / 400 \mathrm{rpm}$ & $\mathrm{Ca}$ & 15.5 \\
& $\mathrm{~K}$ & 14.5 \\
& $\mathrm{P}$ & 17.2 \\
\hline
\end{tabular}




\begin{tabular}{lll}
\hline $2 \mathrm{~h} / 600 \mathrm{rpm}$ & $\mathrm{Ca}$ & 19.0 \\
& $\mathrm{~K}$ & 18.0 \\
& $\mathrm{P}$ & 13.9 \\
\hline $6 \mathrm{~h} / 600 \mathrm{rpm}$ & $\mathrm{Ca}$ & 18.1 \\
& $\mathrm{~K}$ & 18.5 \\
& $\mathrm{P}$ & 13.9 \\
\hline $24 \mathrm{~h} / 600 \mathrm{rpm}$ & $\mathrm{Ca}$ & 17.5 \\
& $\mathrm{~K}$ & 15.3 \\
& $\mathrm{P}$ & 15.3 \\
\hline
\end{tabular}

An Oxisol soil was used in the soil release essays, and it was collected from an agricultural plot - São Carlos city, São Paulo state, Brazil. The main textural characterization according to pipette method (Kilmer and Alexander, 1949) was: sand (663 g kg-1), clay (303 g kg-1 clay) and silt (34 g kg-1). The others chemical and physical soil properties are presented bellow (Table S1):

Table S2 - The chemical and physical soil properties.

\begin{tabular}{|c|c|c|c|c|c|c|c|c|c|c|}
\hline pH & WHC & OM & $P$ resin & $\mathbf{H}+\mathbf{A l}$ & $\mathbf{K}$ & $\mathrm{Ca}$ & Mg & SB & CEC & \multirow[t]{2}{*}{$V \%$} \\
\hline $\mathrm{CaCl}_{2}$ & $\mathrm{~g} / \mathrm{kg}$ & $\mathrm{g} / \mathrm{dm}^{3}$ & $\mathrm{mg} / \mathrm{dm}^{3}$ & \multicolumn{6}{|c|}{$\mathrm{mmolc} / \mathrm{dm}^{3}$} & \\
\hline 4.1 & 200 & 13 & 3 & 31 & 0.4 & 5 & 1 & 7 & 38 & 18 \\
\hline
\end{tabular}

Note: $\mathrm{WHC}=$ water holding capacity; $\mathrm{OM}=$ organic matter; $\mathrm{SB}=$ soil base saturation; $\mathrm{CEC}=$ cation exchange capacity; $\mathrm{V} \%=$ percentage of soil base saturation.

\section{Characterizations}

X-ray diffraction patterns were obtained using an XRD 6000 diffractometer (Shimadzu). The relative intensity of the diffraction peaks was registered in the angular

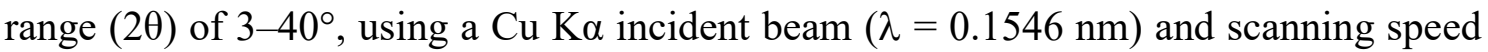
of $2^{\circ} \mathrm{min}^{-1}$ at $30 \mathrm{kV}$ voltage and $40 \mathrm{~mA}$ current. 
Studies of the crystallization behavior of the precursor and samples were carried out using a TA Differential Scanning Calorimeter (DSC) (TA Q100 Controller) with refrigerated cooling system (RCS). Thermal degradation of samples was evaluated in the $25^{\circ} \mathrm{C}-600^{\circ} \mathrm{C}$ range using a $\mathrm{Q} 500$ analyzer (TA Instruments, New Castle, DE, USA) under synthetic air flow of $60 \mathrm{~mL} \cdot \mathrm{min}^{-1}\left(80 \% \mathrm{~N}_{2}\right.$ and $\left.20 \% \mathrm{O}_{2}\right)$ with and heating rate of $10^{\circ} \mathrm{C} \cdot \mathrm{min}^{-1}$.

The thermogravimetric analyses were performed in a Thermogravimetric Analyzer TGA-Q500 (TA Instruments, USA) under synthetic air atmosphere $\left(\mathrm{N}_{2} / \mathrm{O}_{2}\right)$ at a flow rate of $60 / 40 \mathrm{~mL} / \mathrm{min}$ and using platinum crucibles. The temperature range used was $\sim 20$ to $900{ }^{\circ} \mathrm{C}$ at $10{ }^{\circ} \mathrm{C} \min ^{-1}$.

${ }^{31} \mathrm{P}$ NMR MAS analysis were carried out using a Avance III HD / Bruker equipment. The sample was rotated at $10 \mathrm{KHz}$, using the sequence HPDEC (Direct Bias with decoupling) and the chemical shift reference was ADP (Adenosine diphosphate) with phosphate line at $0.8 \mathrm{ppm}$.

\section{Results and discussion}

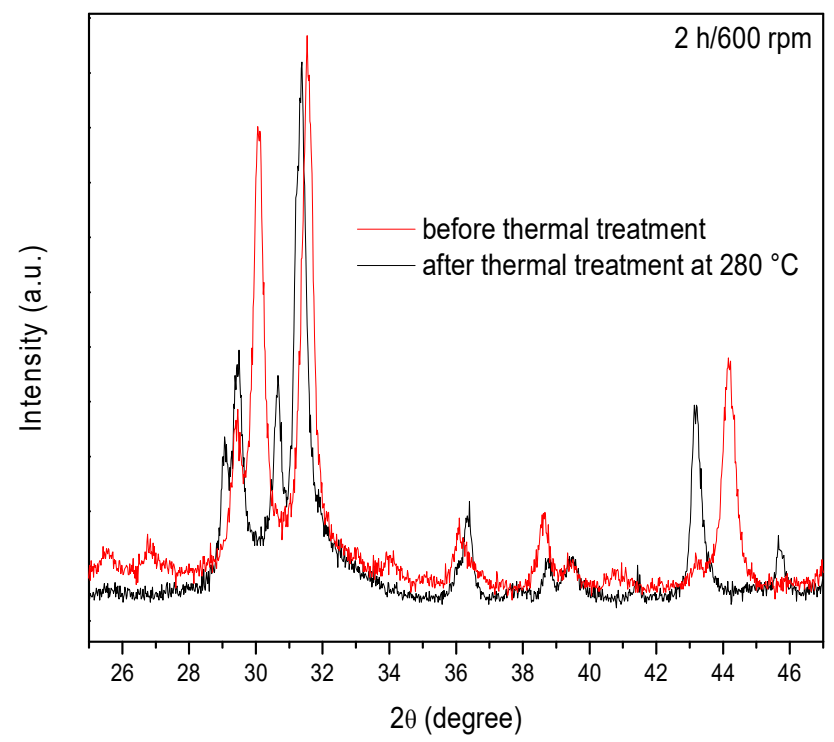

Figure $\mathrm{S} 1-\mathrm{XRD}$ data for $2 \mathrm{~h} / 600 \mathrm{rpm}$ before and after thermal treatment at $280{ }^{\circ} \mathrm{C}$. 


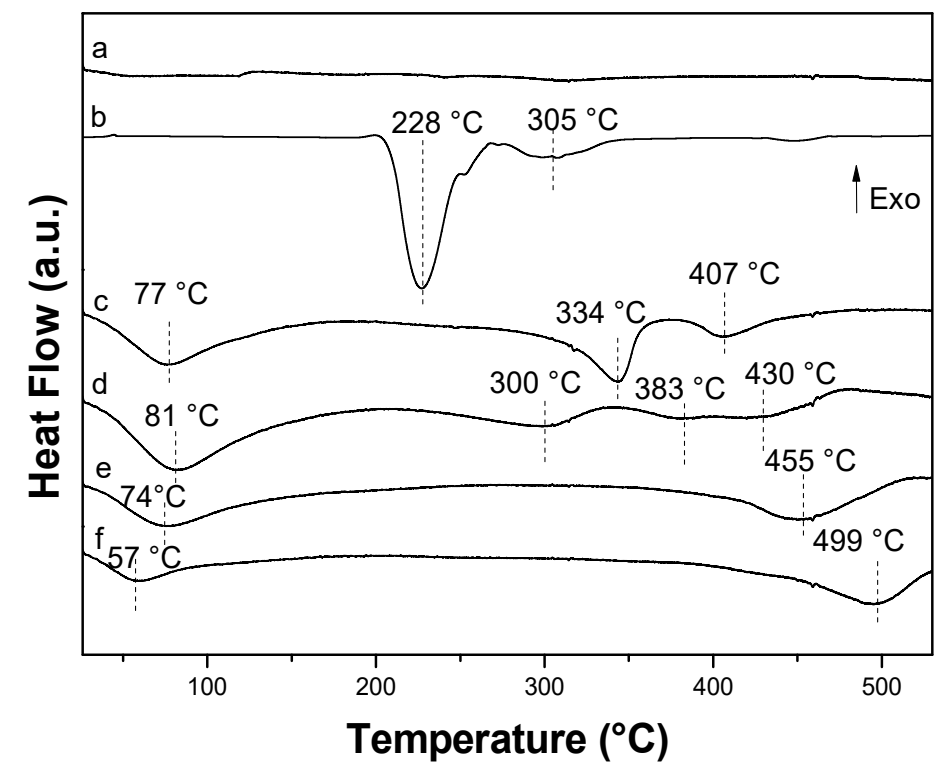

Figure S2 - DSC curves of: untreated eggshell (a); $\mathrm{KH}_{2} \mathrm{PO}_{4}$ (b); 2 h/400 rpm(c), 2 h/600 $\operatorname{rpm}(\mathrm{d}), 6 \mathrm{~h} / 600 \mathrm{rpm}(\mathrm{e})$ and $24 \mathrm{~h} / 600 \mathrm{rpm}(\mathrm{f})$.

\section{Kinetic study in citric acid solution $2 \%$}

Soil release essays

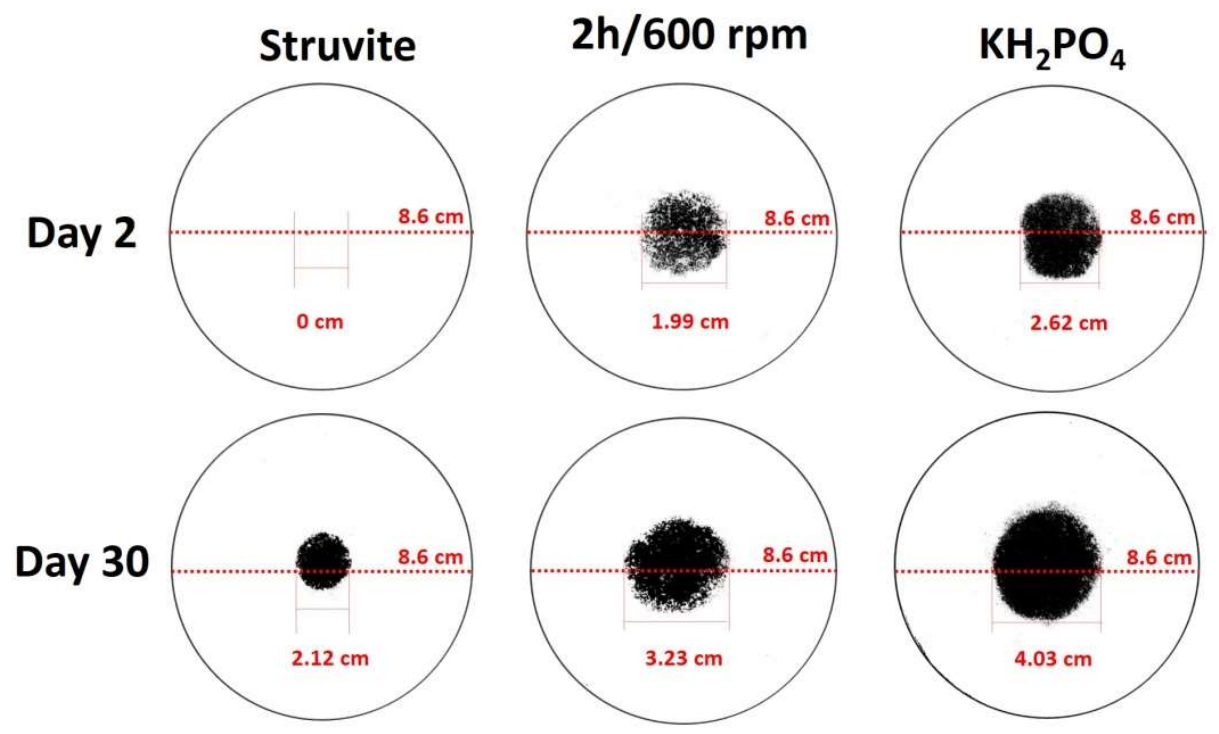

Figure S3 - Visualization of $\mathrm{P}$ diffusion at 2 and 30 days after addition of $\mathrm{P}$ fertilizer in soil. The line delineates the high-P zone as determined by image processing. 


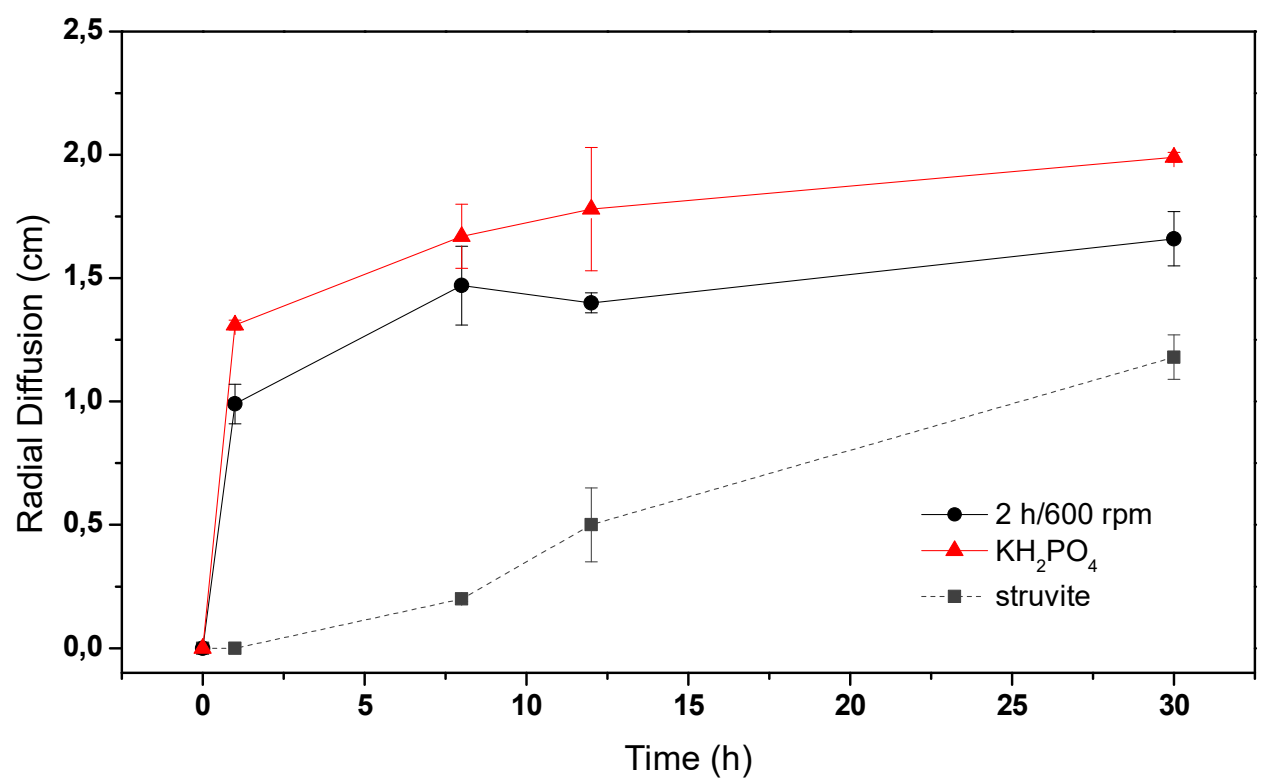

Figure $\mathrm{S} 4$ - Radial diffusion of $\mathrm{KH}_{2} \mathrm{PO}_{4}$, sample $2 \mathrm{~h} / 600 \mathrm{rpm}$ and struvite.

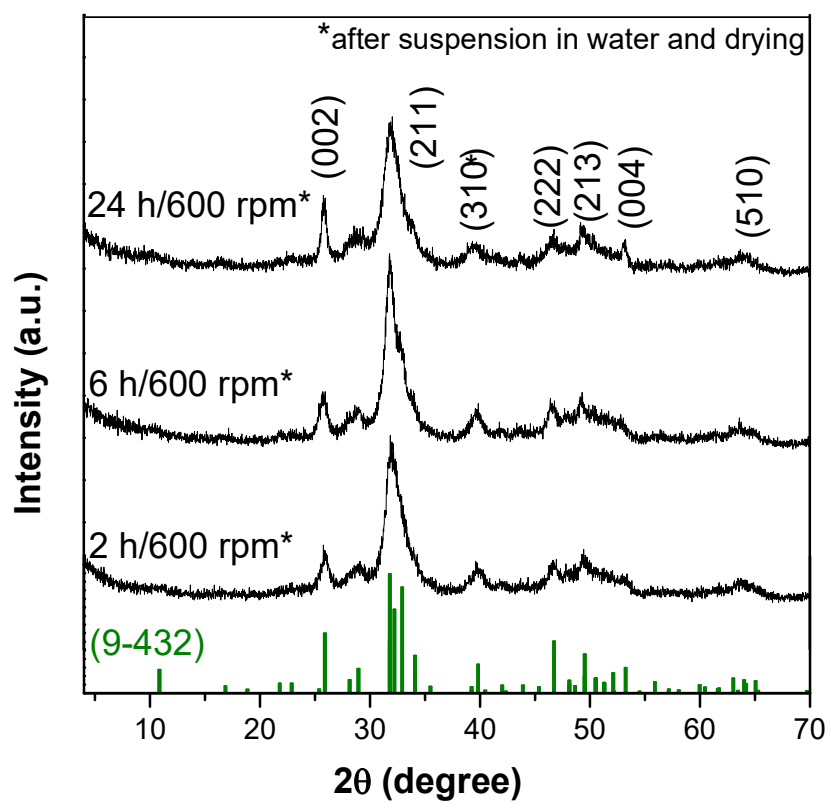

Figure S5 - XRD patterns of all milled samples at $600 \mathrm{rpm}$ after suspension in water and drying. 


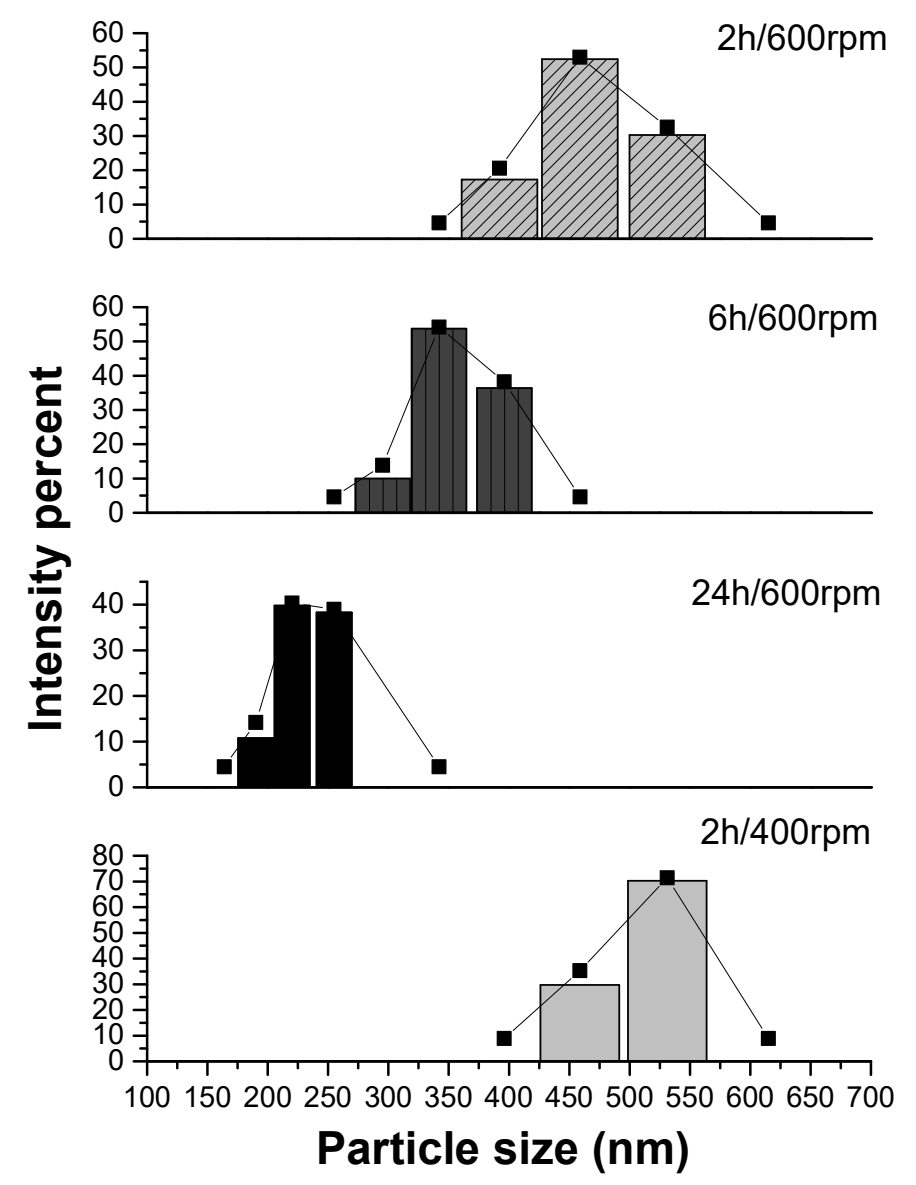

Figure S6 - Particle size distribution for samples milled in different conditions. 